\title{
THE PUZZLE OF PETITIONARY PRAYER
}

\author{
DANIEL \& FRANCES HOWARD-SNYDER
}

Western Washington University

\begin{abstract}
The fact that our asking God to do something can make a difference to what he does underwrites the point of petitionary prayer. Here, however, a puzzle arises: Either doing what we ask is the best God can do or it is not. If it is, then our asking won't make any difference to whether he does it. If it is not, then our asking won't make any difference to whether he does it. So, our asking won't make any difference to whether God does it. Our asking is therefore pointless. In this paper, we try to solve this puzzle without denying either that God must do the best he can or that petitioning God can make a difference to what he does.
\end{abstract}

Father, we pray for your holy Catholic Church; that we all may be one.

Grant that every member of the Church may truly and humbly serve you; that your Name may be glorified by all people.

We pray for all bishops, priests, and deacons; that they may be faithful ministers of your Word and Sacraments.

We pray for all who govern and hold authority in the nations of the world; that there may be justice and peace on the earth.

Give us grace to do your will in all that we undertake; that our works may find favor in your sight.

Have compassion on those who suffer from any grief or trouble; that they may be delivered from their distress.

Give to the departed eternal rest; let light perpetual shine upon them.

We praise you for your saints who have entered into joy; may we also come to share in your heavenly kingdom.

Let us pray for our own needs and the needs of others. ${ }^{1}$

${ }^{1}$ The Book of Common Prayer, The Prayers of the People, Form III 
God, please take the tumor out of Michael's brain and make him all better. $^{2}$

\section{AAAHHHHHHH!!! @\#\$\%!!! Help!}

Sometimes when we pray we ask God to do something. Your friend has just been diagnosed with an inoperable brain tumor; the prognosis is bleak, so you ask God to heal him. You're alone in the backcountry, just north of Chikamin Ridge at Park Lake in the Central Cascades; it's 3:20am, and the bear you ran off twenty minutes ago is back in your camp, grunting and tearing at the ground. You clutch your knife, scream, and bang your pot; the bear charges. You implore God to intervene. It is reasonable for you to want God's help on such occasions; matters are desperate and you can't do anything about them. God can help you, of course; indeed, he wants to help you.

But why bother to request his help? It won't give him any information he doesn't already have; nor will it prod him to do what he knows he should do. He's perfectly aware of the gravity of the situation and, unlike most of us, he doesn't need prodding. Moreover, God will do the best he can do. Thus, if healing your friend and stopping the bear are the best he can do, he will do them whether you ask or not; and if they are not the best he can do, he will not do them whether you ask or not. So whether you ask or not won't make any difference to what he does.

This conclusion flies in the face of what most practicing theists assume. They assume that sometimes asking God to do something will make a difference to what he does and they are encouraged in this assumption by the example and admonition of religious authorities. ${ }^{4}$ If it is false however, the practice of petitionary prayer appears pointless. After all, what's the point of petitioning God if it doesn't make any difference to what he does?

${ }^{2}$ Peter Howard-Snyder, evening prayer, May 12, 2005.

${ }^{3}$ Dan Howard-Snyder, prayer at Park Lake, 3:20am, August 13, 2006.

${ }^{4}$ In the Christian tradition such notable commendations include: "You do not have, because you do not ask God" (James 4:2), "Ask, and it will be given to you: seek, and you will find; knock, and it will be opened to you" (Matthew 7:7), and "Pray for each other so that you may be healed" (James 5:16). Cf. Colossians 4:3, 2 Corinthians 1:11, John $17: 20-21$. 


\section{THE ARGUMENT}

We can generalize this puzzle, the puzzle of petitionary prayer, and express it in the form of an argument as follows:

\section{The Argument}

1. Either doing something is the best God can do or it is not.

2. If it is the best God can do, then your asking won't make any difference to whether he does it.

3. If it is not the best God can do, then your asking won't make any difference to whether he does it.

4. So, your asking won't make any difference to whether God does it. $^{5}$

What should we make of The Argument?

Some people suggest that even if petitioning God won't make any difference to whether God does it, it still has a purpose since it can make a difference in us. Petitioning God can increase our awareness of our own needs and the needs of others and thus increase the likelihood of our acting to meet those needs; it can help us to reorient our focus, from evil to good, from despair to hope; it can prepare us to receive God's gifts with gratitude and it can promote recognition of their source. ${ }^{6}$ As novelist George Meredith put it: "Who rises from prayer a better man, his prayer is answered".

${ }^{5}$ Two notes in one. (i) The Argument resembles one that appears in Stump 1979, 83-84; Basinger 1995, 475; Murray and Meyers 1994, 311-12; Basinger 2003, 257. (ii) The premises are true only if they are necessarily true. Hence, the conclusion is more aptly put "So, your asking cannot make a difference to what God does".

${ }^{6}$ John Calvin writes: "Prayer is not so much for his sake as for ours. . .it is very much for our interest to be constantly supplicating him: first, that our heart may be always inflamed with a serious and ardent desire of seeking, loving and serving him, ... secondly, that no desire, no longing whatever, of which we are ashamed to make him the witness, may enter our minds ... and lastly, that we may be prepared to receive all his benefits with true gratitude and thanksgiving, while our prayers remind us that they proceed from his hand." (1536; 1979, 147). See also Murray and Meyers 1994; Murray 2003a; Murray 2003b.

${ }^{7}$ Quoted in Flint 1998, 21. 
We agree that petitioning God can make a difference in us. However, as we noted above, most practicing theists assume there is more to it than that and so it would be more charitable to solve the puzzle without denying their assumption. Moreover, even if petitioning God can make a difference in us, we cannot petition him while thinking that our words won't make any difference to whether he does what we ask. That's because, in general, our words do not constitute the speech act of petitioning if we think that our words won't make any difference to whether the petitioned does what we ask. ${ }^{8}$ Therefore, no matter what words we use, and even if they would typically be used to perform a speech act of petitioning, they do not constitute an act of petitioning God if we think that they won't make any difference to what God does. It behooves us, therefore, not to accept the conclusion of The Argument if we wish to engage in the practice of petitionary prayer.

But how can we? Well, we might note that The Argument presupposes that God must do the best he can do. Some people suggest that this presupposition is false. Although we are not averse to this suggestion, ${ }^{9}$ we will grant for the sake of argument that it is true.

In what follows, we aim to bring a crucial assumption of The Argument to light (section II). We will then briefly consider one basis for rejecting it (section III) and develop in more detail and defend a second basis for rejecting it (sections IV-VII).

${ }^{8}$ One piece of evidence in favor of this is the standard conjunction test. Consider cases in which a speaker uses a sentence that would normally be used in a specified context to make a petition and conjoin it with the denial of the condition in question; if the conjunction leaves us in doubt about whether she made a petition with that sentence, then we have evidence to regard the condition as partially constitutive of the act of petitioning. Thus, for example, if you were to say to a family member, "I realize that what I'm about to say won't make any difference at all to what you do, but would you please pass the salt?", your words would not count as a petition but rather as an insult or a joke, or at best a mere expression of desire. Similarly, if a wife prayed to God, "I ask that you heal my husband, although I realize that what I say won't make a bit of difference to what you do," her words would not constitute a petition either.

${ }^{9}$ Howard-Snyder 1994. 


\section{BRINGING THE CRUCIAL ASSUMPTION TO LIGHT}

Consider the following general point: our bringing about a state of affairs in response to a petition can be better than the alternatives.

This is a common feature of human life. For example, Michael Murray points out that there are times when our doing things for our children because they ask is better than not doing them at all or doing them absent a request. ${ }^{10}$ Suppose a mother considers buying a book about spiders for her son, Peter, knowing that he would enjoy it. Suppose it is better that she buy one rather than not. Then she recalls that she has bought him many books in the past and considers whether her buying a book in response to his asking might be better than her buying a book unasked. If she brings Peter to the store and he finds a book for himself and asks for it, he will have more control over whether and what he reads-she won't simply be raining down books from on high. Moreover, he might feel more grateful if she buys a book because he asked. Similarly, if she waits for Peter's twin, William, to ask her to play a game of chess, he will have taken some initiative with respect to their growing relationship as well as his own development as a chess player-taking initiative has some value in addition to the value of simply playing the game together.

Here's another general point to consider: our asking others to do something can change the moral status of their doing it, all by itself, independently of any other reason we have to do it.

This too seems to be a common feature of human life. Suppose you have just as much reason to do something for another person as not. Then, if you don't do it, you won't be acting wrongly. But now suppose he asks you to do it. In that case, the moral terrain changes: you now have more reason to do it, in which case if you don't do it, you'll be acting wrongly. To illustrate the point, suppose you're working on a paper in your study. You look outside the window and notice your neighbor at the curb with a suitcase, peering down the street, anxiously glancing at his watch. It's obvious that he's expecting a ride and it's late. You consider whether you ought to offer a lift but decide that, in the circumstances, given your deadlines, schedule, and the like, you have just as much moral

${ }^{10}$ Murray and Meyers 1994, 316. 
reason to continue working as to give him a lift. You conclude that if you don't give him a ride, you won't be acting wrongly and so you continue working. Suppose you're right. Two minutes later, you hear the doorbell and answer it. Your distraught neighbor tells you that his ride is late; he asks you for a lift. Although you have learned nothing new-it was obvious that his ride was late and that he was distraught-his request nevertheless changes the moral terrain. It provides a reason for you to give him a ride, a reason that you didn't have before. In its absence you had just as much reason to continue working as to give him a lift but you now have more reason; therefore you act wrongly if you do not.

Both of these general points seem to apply, at least in principle, to divine-human relations; if they in fact do, then premises (2) and (3) are both false. Here's why.

Consider the first point. Suppose that God's bringing about a state of affairs in response to a petition can be better than the alternatives. Then it might be that, on some particular occasion, the act of bringing about a certain state of affairs is such that, if you do not ask him to do it, he will not do it, but if you ask him, he will since, if you ask him, doing it is the best he can do, but if you don't it isn't. In that case, doing something might be the best God can do given that you ask him to do it, and so your asking him would make a difference to whether he does it. Likewise, doing something might not be the best God can do given that you do not ask him to do it, but, if you asked him, it would be the best he could do and so asking him would make a difference.

Now consider the second general point. Suppose that asking God to do something can change the moral status of his doing it, all by itself, independently of any other reason he has to do it. Then it might be that, on some particular occasion, the act of bringing about a certain state of affairs is such that, if you do not ask, then God has as good a reason to do it as not, in which case he is permitted not to do it; but, if you ask, then he has more reason to do it than not, in which case he ought to do it and doing it is the best he can do. Therefore, doing something might be the best he can do, given that you ask him to do it, but not otherwise, in which case your asking would make a difference to whether he does it. Likewise, doing something might not be the best God can do given that you do not ask him to do it, but, if you were to ask, your request would 
give him a reason he otherwise wouldn't have and so asking him would make a difference. ${ }^{11}$

The upshot is that if God's bringing about a state of affairs in response to a petition can be better than the alternatives or if asking God to do something can change the moral status of his doing it, all by itself and independently of any other reason he has to do it, then premises (2) and (3) of The Argument are both false. So premises (2) and (3) are both true only if a Crucial Assumption (CA) is true:

CA. God's bringing about a state of affairs in response to a petition cannot be better than the alternatives, and asking God to do something cannot change the moral status of his doing it, all by itself, independently of any other reason he has to do it.

What should we make of CA?

\section{HOW ASKING GOD TO DO SOMETHING CAN CHANGE THE MORAL STATUS OF HIS DOING IT}

Geoffrey Cupit's account of how requests generate moral reasons suggests that, contrary to CA, asking God to do something can change the moral status of his doing it, all by itself, independently of any other reason he has to do it. Cupit argues that just as making a promise generates a moral reason to do what was promised, a reason above and beyond other reasons to do it, so do requests, the difference being that promises in and of themselves give the promiser a moral reason to do what was promised whereas requests in and of themselves give the requestee a moral reason to do what was requested. But how, exactly, do requests do that?

Cupit begins with the observation that people often already know what we need and our request simply draws their attention to it. On oth-

${ }^{11}$ Alternatively with respect to the second general point: suppose God has nearly enough reason to do something as not. In that case, he will not do it since he has more reason not to do it than to do it. But if asking him to do it gives him a reason to do it independent of any reason he already has, and if that reason is weighty enough, it might tip the balance of reasons in favor of doing it over not doing it, in which case God ought to do it and it is the best he can do. 
er occasions, people don't know what we need and our request provides needed information. "But," he says,

it is not necessary for attention to be drawn, or information given, by the making of a request. It is enough to achieve this end simply to state that the wish exists. If we were to believe that requests do no more than refer to existing reasons we should be unable to see the point of a request, as against the mere expression of a wish. ${ }^{12}$

Since requests are not merely expressions of a wish, Cupit concludes that

requests are attempts to affect the actions of others, and the attempt is made by providing a reason to act which the requestee would not otherwise have. Requests, by their nature, must be supposed to generate reasons for action. $^{13}$

So, says Cupit, our requests give others an independent reason to act, a reason above and beyond any other reason they might have, since our words could not constitute the speech act of requesting as opposed, say, to the speech act of merely expressing desire, unless they provided such an independent reason.

But even if requests give independent reasons to act, what makes them moral reasons, reasons that generate defeasible obligations to do what was requested?

The mechanism Cupit suggests is basically this. When someone makes a request, she treats the requestee as caring or regardful; indeed, by making the request she expresses her trust that he will treat it as a reason to act. However, she runs the risk of being degraded, of being "made a fool of" for trusting him to be the sort of person who would treat her request as a reason to act when in fact he is not. She makes herself vulnerable to him; she puts herself at the mercy of his goodwill. Now: in general, we have a defeasible obligation not to degrade another human being, especially when she is vulnerable to us. Thus, upon hearing a request, the requestee has a defeasible obligation to regard the request, all by itself, as a reason to act.

\footnotetext{
${ }^{12}$ Ibid.

${ }^{13}$ Ibid.
} 
Naturally enough, there are objections to Cupit's account. Since our focus lies elsewhere, we will leave an assessment of it for another occasion. ${ }^{14}$

\section{HOW GOD'S BRINGING ABOUT A STATE OF AFFAIRS IN RESPONSE TO A PETITION CAN BE BETTER THAN THE ALTERNATIVES}

Consider what we might call the institution of petitionary prayer, things being set up by God in such a way that, on occasion, he will bring about a good state of affairs if and only if we ask him to. Suppose he decrees this institution. Then, on occasion, God will do something only if we ask. Of course, God could make us ask; alternatively, he might leave it up to us. Suppose the institution he decrees involves his leaving it up to us. Then, as a matter of logical necessity, God must on occasion leave it up to us to ask him to do something instead of doing it unasked. Now: God cannot do that unless he leaves it up to particular individuals to ask on particular occasions. He might not have any particular individuals or occasions in mind in his decree but, whether or not he does, particular individuals on particular occasions must ask; otherwise, God won't act. Consider such an occasion, one that involves, say, you. Then, on that occasion, God's bringing about a good state of affairs in response to your petition can be better than the alternatives precisely because bringing it about in response to your petition serves to help realize the institution of petitionary prayer.

But why suppose that the institution of petitionary prayer is valuable enough for God to decree it? The answer we favor is this: because, in general, it is a good thing for us to be responsible for our own welfare and the welfare of others and, as Richard Swinburne observes, the institution of petitionary prayer helps to serve that purpose. ${ }^{15}$ In the same

${ }^{14}$ For some of those objections and an attempt to restrict Cupit's account to requests within the boundaries of personal relationships, see Gellman 1997.

${ }^{15}$ Swinburne 1998, 115. Of course, petitions are no substitute for our feeding the hungry, clothing the destitute, visiting the sick, living simply so we can send half our income to World Vision, and the like, if we can. Petitioning God needn't be passing the buck. 
vein, Isaac Choi says that the institution of petitionary prayer "gives us a practical opportunity to love others, especially in those situations when there is not much else we can do to readily help them" ${ }^{16}$ In short: if God sets things up so that he brings about some good states of affairs if and only if it's up to us to ask and we ask, we exercise responsibility for our own welfare and that of others and the reach of our love is extended. That's what makes the institution of petitionary prayer valuable. ${ }^{17}$

Or so Swinburne and Choi say, and we concur. As might be expected, there are objections to consider. In what follows, we assess three of them.

\section{DAVISON'S OBJECTION TO SWINBURNE'S SUGGESTION}

Scott Davison objects to Swinburne's claim that the institution of petitionary prayer is a way for us to exercise responsibility. "[I]t is impossible," he says, "to reasonably believe that one's petitions are ever granted," direct revelation aside. In that case, he continues,

it seems unlikely that one is responsible (in any substantial sense) for the results of God's granting them. This is because, in general, one's degree of responsibility for the obtaining of some state of affairs depends upon the degree to which one could foresee its obtaining given one's actions, the degree to which one intended that it obtain as a result of one's actions, and the degree to which one's actions contributed causally to its obtaining. So cases in which one person petitions another person to act freely in specific ways over time, especially when one does not know the outcome of such petitions, are cases in which one's responsibility for the obtaining of the state of affairs in question is dramatically diminished. ${ }^{18}$

At the most general level, Davison's argument is clear. Suppose one has no direct revelation that one's petition was granted by God. Then, even if the institution of petitionary prayer is in place,

${ }^{16}$ Choi unpublished, 12.

${ }^{17}$ In what follows, we will drop the "it's up to us to ask" clause for the sake of simplicity and only use the "we ask" clause, but it should be understood that both clauses are in place.

${ }^{18} 2009,296$, lightly edited. 
1. It is impossible for one to reasonably believe that one's petition was granted by God.

2. If it is impossible for one to reasonably believe that one's petition was granted by God, then one is not responsible (in any substantial sense) for the results of God's granting it.

3. So, one is not responsible (in any substantial sense) for the results of God's granting one's petition. $(1,2)$

What should we make of this argument? We make three points in response.

\subsection{So what?}

Suppose the conclusion is true. Responsibility comes in degrees, and one is, let's say, only somewhat or minimally responsible for the results of God's granting one's petition. That seems sensible, you might think. You ask God to heal your friend of her cancer. You sure don't have the power to do it on your own; you have no power over the laws of nature, the elementary particles, the genetics of cancer cells, and so on; indeed, you don't even have the power to maintain your own existence moment-tomoment. But God does. And you didn't set up the institution of petitionary prayer either. But God did. No surprise, then, that your responsibility for her being healed seems minimal. Suppose it is.

But how does any of this imply that the institution of petitionary prayer does not extend human responsibility? We don't see how. After all, even if you are only somewhat responsible for your friend's being healed, your free petition was necessary and sufficient for it given that the institution was in place. That's responsibility enough. ${ }^{19}$ The truth is, however, that we see no reason to grant Davison's conclusion in the first place.

${ }^{19}$ Perhaps Davison will reply: "If God really wants to extend responsibility for the world, there must be a better way." Indeed: that's exactly what he does say $(2009,302-303$, note 26). But again: suppose he's right. For the sake of simplicity, suppose there are exactly two ways to extend human responsibility: the institution of petitionary prayer and the other, better way. So what? It certainly doesn't follow that God won't extend it through the institution of petitionary prayer. After all, extending it through both is an option. Indeed, it might even be that the better way includes the institution of petitionary prayer. 


\subsection{Is it impossible to reasonably believe that one's petition was granted by God? \\ Let's begin with premise (1) of the argument, the claim that it is im- possible for one to reasonably believe that one's petition was granted by God, absent direct revelation. (Let's interpret the modality here charita- bly and let's not fuss about what theory of reasonable belief is in ques- tion.) Why suppose it's true? Davison writes:}

Given the complexity involved in saying that God does something because we ask, it seems impossible, apart from direct revelation, for any of us ever to reasonably believe that any particular petition has ever been granted because we asked. In order to see that this is so, suppose that every event is produced by God in some sense, as traditional theists have typically insisted. Even if this is the case, apart from direct revelation, there is no way to have enough access to God's reasons for bringing things about to be able to distinguish events brought about because we asked and events God brought about for other reasons after we happened to ask. Since we can't distinguish these things, the only reasonable thing for us to do is withhold judgment on the matter. ${ }^{20}$

What should we make of this line of thought?

On this score, the authors of the present paper disagree. So we offer both points of view, each in the first-person singular.

Author \#1. A degree of intellectual humility is appropriate when it comes to believing God has granted a particular petition. In my experience, devout believers are far too quick to assume that some fortunate occurrence-a healing, an empty parking space, a chess trophy-was the result of God's granting their petition. At the same time, it seems a little extreme to say that one can never reasonably believe that God has granted one's request. Just as we sometimes reasonably believe that, on certain occasions, other people do things because we asked-despite the immense difficulty in saying how that can be-why can't we sometimes reasonably believe that, on certain occasions, God does something because we asked?

${ }^{20}$ Davison 2009, 293, lightly edited. As for the "complexity" of which Davison initially speaks (perhaps he meant "difficulty"), we take it that he means to say that it remains perplexing how anyone, human or divine, can do things for reasons, especially when those things are done freely (as conceived by libertarians). 
Let's get a real-life example before us. Misty visits the doctor for her severe, chronic back pain. After some tests, he informs her on the third visit that there's nothing to be done about it; her pain will almost certainly stay with her the rest of her life. He gives her a prescription for painkillers. She drives to the pharmacy. As she exits her car, the pain suddenly vanishes. Amazed, she walks around a bit in the parking lot. Uncertain whether to trust this change, she picks up her prescription, shops, and returns to her car. She calls her husband, Cavin, on her cell phone to tell him what happened. "What time did the pain go away?", he asks. She replies: "11:05. I had just finished listening to the NPR news headlines." "That was exactly the time our prayer group was praying for healing for you," he says.

In this situation, Misty and Cavin reasonably believe that God healed Misty because Cavin's group asked. Or so I say. Of course, they aren't absolutely certain but that's not necessary for reasonable belief. Whether their belief is reasonable depends on their background beliefs. Those who deny or who are in doubt about whether God has set the institution of petitionary prayer in place do not reasonably believe that God healed Misty because Cavin's group asked. But those who, like Misty and Cavin, believe that God has set it in place may well do so.

The situation is analogous to our beliefs about people granting particular requests. If you write to a philosopher and ask for a copy of her paper, and two weeks later you receive it (without an accompanying letter), you reasonably believe that she sent it to you because you asked. You reasonably believe this because of your background belief that people sometimes do things because they are asked. But if Misty and Cavin have the analogous background belief that God sometimes does things because he is asked, then they too can reasonably believe that God healed Misty because Cavin's group asked. ${ }^{21}$

Of course, coincidences happen. You write to the philosopher and ask for the paper but she never gets your letter; it occurs to a friend of hers, however, that you might be interested in it and so he suggests that she drop a copy in the mail to you. She does. It arrives two weeks after you posted your letter. But to insist that your belief that she sent the paper because you asked is reasonable only if you rule out coincidences like this

\footnotetext{
${ }^{21}$ Cp. Murray 2003b, 263-64.
} 
implies absurdly high conditions on reasonable belief about people doing things because we asked. Likewise, even though we can't rule out the possibility that Misty's pain disappeared at 11:05 for some purely natural reason, it does not follow that Misty's and Cavin's belief that God healed Misty because Cavin's group asked is not reasonable. ${ }^{22}$

So let's set aside purely natural coincidence and focus on alternative explanations for the disappearance of Misty's pain at 11:05. Indeed, let's suppose, as Davison does, that God healed Misty at 11:05. Even so, says Davison, we should be in doubt about whether he did so because Cavin's group asked. But why suppose Davison's right? Consider the three most salient options:

(a) God healed Misty at 11:05 because Cavin's group asked then.

(b) God healed Misty at 11:05 because God had an independent reason to heal her then.

(c) God had an independent reason to heal Misty at some time or other and he randomly selected one.

If I understand Davison correctly, he would claim that (b) or (c) explains the disappearance of Misty's pain at 11:05 at least as well as (a), and hence that even if we believe God healed Misty at 11:05 we should be in doubt about whether it was because Cavin's group asked. However, neither (b) nor (c) explain why God healed Misty at 11:05 as well as (a). On (a), it's very likely and understandable that the healing occurred at 11:05. On (c), it isn't likely at all. On (b), it's likely that the healing occurred at 11:05 but it cries out for more details. What could God's reason be for acting then if not the request of Cavin's group? Of course, we aren't in a position to rule out such a reason. But what should we conclude from that? If a window breaks upon being struck by a baseball, we are in no position to rule out some alternative cause of its breaking at that time, e.g. a hidden weakness in the molecular structure that just happens to give way then, but we reasonably blame the boy with the glove. Likewise, even though Misty and Cavin are in no position to rule out God's having an independent reason to heal Misty at 11:05, they reasonably believe he did so because Cavin's group asked.

${ }^{22}$ The professor case is from Murray and Meyers 1994, 321-22. 
Author \#2. I agree that a degree of intellectual humility is appropriate when it comes to believing that God has granted a particular petition, and I even agree that it is seems extreme to say that we can never reasonably believe that God has granted our request. Nevertheless, that is the position that the appropriate degree of intellectual humility leads to, absent direct revelation. Misty's case is a case in point. Four observations are relevant.

First, the degree of reasonableness of Misty's and Cavin's belief that God healed Misty because Cavin's group asked can be no greater than the degree of reasonableness enjoyed by their background beliefs, notably their belief that God exists and that he's in the business of granting petitions. To be sure, they have a high degree of confidence about these matters, but that doesn't add up to reasonable belief; moreover, if you examine the basis of their belief, I think you'll see that the degree of reasonability is at best quite low.

But let's put all that aside. Let's suppose that God exists, that he set the institution of petitionary prayer in place, and that their belief in these things is maximally reasonable. The issue, then, is whether there is enough evidence to think that Misty's case is one of those times when God does something because we asked-specifically whether there is enough evidence to think God healed Misty at 11:05 because Cavin's group asked then.

Second, we can't marginalize purely natural causes. They must be kept on the table. Like other ailments, chronic back pain sometimes disappears due to indiscernible natural causes. Nerves get unpinched, tight muscles suddenly relax, and so on. The role of stress and its relief with respect to chronic pain is generally poorly understood. A purely natural cause isn't nearly as unexpected as the coincidence you describe involving the professor sending the paper without receiving the request.

Third, we can imagine independent reasons ad nauseum for God to heal Misty at 11:05, reasons that for all we can tell God acted on apart from the request by Cavin's group. For example:

Independent reason \#1. God healed Misty at 11:05 because (a) 11:05 was after her 10:15 doctor's appointment and God wanted Misty's doctor to practice giving bad news to patients (something he's been trying to get better at) and God wanted Misty to virtuously respond to receiving it, and (b) during the 
drive to the pharmacy Misty wrestled with her prognosis-she even pulled over on the shoulder to weep, in rage and sorrow-but, as she got out of the car at the pharmacy, she finally internally displayed the sort of trust, courage, and hope that God wanted from her. That's why he healed her. The time was 11:05.

There are many such stories involving independent reasons and we are in no position to rule them out. They are all on the table competing with the hypothesis that God healed Misty at 11:05 because Cavin's group asked.

Fourth, for twelve months, Cavin's group has met every week and each time they prayed for Misty. There are two points related to this fact.

(i) Approximately one out of every 168 hours of each week, Cavin's group asked God to heal Misty. If God had an independent reason to heal her during some one hour stretch or other, there's a 1/168 chance that he would do it during an hour in which the group was praying. So it's not nearly as statistically unlikely that God would heal her for an independent reason at a time when the group was praying, not nearly as unlikely as you suggest with the baseball analogy. The fact that the molecular structure of the window just happened to give way when the ball struck is massively unlikely, much, much more unlikely than Cavin's group praying when God acted on independent reason to heal Misty at 11:05, if he did. (I assume that your case would not be undermined if Cavin's group had prayed for Misty at 10:05. Surely God can do something because we asked even if it's an hour after we made the request.)

(ii) You say that God's having an independent reason to heal Misty at 11:05 "cries out for more details. What could God's reason be for acting then if not the request of Cavin's group?" I'm not sure what your point is here. We can cook up detailed independent reasons willy-nilly. However, contrary to what you suggest, God's healing Misty at 11:05 because that's when Cavin's group asked does "cry out for more details". Why did God do it then and not one of the fifty-one other times that Cavin's group prayed over the past year? And why did he do it then rather than one of the 364 times Misty asked in her daily prayers over the past year? And so on. You say it's understandable that God healed her at 11:05 given that God did so because Cavin's group asked then. Perhaps so, but without answers to these questions, it's not so clear that it is more understandable than any of the detailed independent reasons we can think of. 
Without trying to connect the dots between these points, I submit that if we appreciate them properly, we will be in doubt about whether, on this particular occasion, God healed Misty at 11:05 because Cavin's group asked then. Whether some other case would illustrate how it might be reasonable to believe that God did something because we asked remains an open question. All we can do is proceed case by case.

(Here ends the authors' disagreement.)

\subsection{Is inability to foresee sufficient for insubstantial responsibility?}

We now turn to premise (2) of Davison's argument, the claim that if it is impossible for one to reasonably believe that one's petition was granted by God, then one is not substantially responsible for the results of God's granting it. Why suppose it's true? Because, says Davison, in general, one's degree of responsibility for the obtaining of some state of affairs depends upon the degree to which several conditions are satisfied, and if it is impossible for one to reasonably believe that one's petition was granted by God, then those conditions can only be satisfied to a degree which, at best, implies minimal responsibility for its obtaining. What are those conditions? There are three, says Davison:

(i) one could foresee the state of affairs obtaining given one's actions,

(ii) one intended that it obtain as a result of one's actions, and

(iii) one's actions contributed causally to its obtaining.

What should we make of this line of thought?

We grant, for the sake of argument, that it's impossible for one to reasonably believe that one's petition was granted by God. But we don't think that it follows that one is not substantially responsible for the obtaining of the state of affairs one prayed for.

Recall that we are supposing, for the sake of illustration, that the institution of petitionary prayer is in place and, thus, that your friend will be healed if and only if you ask. Now suppose you ask; as a result, God heals her and so she's healed. Consider condition (iii): to what degree has your action contributed causally to her being healed? It's difficult to know how to answer this question, but it seems that whatever degree it is, it won't be significantly less than the degree to which you contribute 
causally in bringing about various mundane states of affairs. This is not surprising; after all, your freely asking is necessary and sufficient for her being healed, given that the institution of petitionary prayer is in place. To be sure, you didn't set the institution in place, but then we didn't set in place the standing conditions that allow us to contribute causally to the way the world is. Indeed, it seems we had no greater influence on those conditions than the institution in question, in which case it seems that the degree to which your asking contributes causally to your friend's being healed is no less than the degree to which a particular act of yours contributes causally to, say, the tennis ball's landing a winner or the sockeye and zucchini being grilled to perfection.

As for condition (ii), suppose you fully intend for your friend to be healed as a result of your asking. In that case, two of Davison's three conditions appear to be satisfied to a degree that would render your responsibility for your friend's healing fairly substantial, a degree that is at least nearly as great as that which would render your responsibility for bringing about various mundane states of affairs fairly substantial.

So Davison must be placing a lot of weight on condition (i). ${ }^{23}$ That is, it appears that Davison thinks that if one cannot foresee that a state of affairs will obtain given one's actions, then one's degree of responsibility is insubstantial. Inability to foresee is sufficient for insubstantial responsibility. Let's look into the matter a bit more closely.

Suppose you rightly think that the institution of petitionary prayer is in place; furthermore, you can't foresee your friend being healed given your petition. Your faith is a faith without sight. As it turns out, unbeknownst to you, this is one of those occasions where God will bring about a good state of affairs if and only if you ask. In that case, either you ask and she's healed, or you don't and she's not. You ask. As a result, she's healed. Of course, you can't tell whether God healed her because you asked or for some other reason, or whether the chemo happened to work or what. Nevertheless, as a matter of fact and unbeknownst to you, in the circumstances, your asking was necessary and sufficient for her healing. If we understand Davison correctly, he thinks that, in this case, you are

${ }^{23}$ Of course, there is the nasty question of how to weight these conditions, a question we expect will not admit of a well-known principled answer. But let that pass. 
not substantially responsible for your friend's being healed. Why? Because you can't foresee your friend being healed given your request.

This doesn't seem right to us.

Consider another case. Suppose a nuclear facility is about to malfunction due to a leak; a town will be destroyed if it does. An engineer volunteers to seal the leak. Unfortunately, the only procedure for placing the seal has a notoriously unreliable track-record. He knows this and so he can't foresee that his placing the seal will result in the townspeople being saved. However, he fully intends for his action to have that result. Now, unbeknownst to him and as a matter of fact, if a seal is placed on that particular leak, the facility will not malfunction and the townspeople will be saved. Therefore, unbeknownst to him but as a matter of fact, in the circumstances, placing a seal is necessary and sufficient for the townspeople being saved. He freely places the seal; the town is saved. He is responsible for that result-in a substantial sense, not in a minimal, some-what-ish sense. Therefore, even if one cannot foresee that a state of affairs will obtain given one's actions, one's degree of responsibility for its obtaining might nevertheless be substantial.

Davison might object. For while the engineer risks his life in sealing the leak, those who pray do no such thing. Consequently, even if those who practice petitionary prayer can be responsible for the outcome, they are at best minimally responsible. It costs very little to merely ask for a favor.

In response, note that most theistic traditions hold that not all petitions are equally efficacious. The more sincere, the more ardent, the more detailed, the more persistent petitions are more likely to be granted, other things being equal. And God is more likely to grant the petitions of the faithful or virtuous than those of the unfaithful or vicious. Merely saying "Please heal my neighbor" may move God less if the petitioner does not wholeheartedly want the request to be granted or if she lacks faith that God will grant the request or if she lacks standing with God. Getting into the right frame of mind and getting into good standing with God may well be costly. In that case, our degree of responsibility for the good that comes about through God's granting our petitions might be quite substantial.

We conclude that Davison's objection does not give us good reason to reject Swinburne's suggestion. 


\section{DAVISON’S OBJECTION TO CHOI'S SUGGESTION}

Davison also rejects Choi's claim that if God decrees the institution of petitionary prayer in place, our prayers amount to acts of love, and the institution can be thought of as extending the reach of our love, especially to those who are distant from us. According to Choi, this is one way in which God allows us to make a difference in the world for the good. Davison has three worries about Choi's suggestion but the third worry, he says, is the most fundamental. ${ }^{24}$ Here it is:

Since God can freely decide not to answer any particular prayer, . . . it is not clear that we can describe answered prayers as acts of love performed by the petitioners. The offering of a petition might be an act of love performed by the petitioner, but the answering of the prayer would be an act of love performed by God, not by the petitioner. (If the offering of the petition is itself an act of love, then it is a good thing, but this will be true whether or not it is answered. ..) Choi's point is that God 'leaves room' for us to make a difference in the lives of others, but it would be the answering, not the petitioning, that would make a difference in the world, and the petition does not cause the answering so long as God is free. Hence God should get the credit for the answered prayer, not the petitioner, which undercuts Choi's point that God leaves room for creatures to make a difference in the world..$^{25}$

${ }^{24}$ First worry: Davison cites C.S. Lewis's claim that "often people pray for others when they should be helping them instead," and implies that Choi's suggestion should be restricted to "prayers for those whom we cannot help ourselves" (297). We don't see the need for any such restriction. There are lots of ways to help those we can directly affect who are in need and, if the institution of petitionary prayer is in place, perhaps it provides another way. Second worry: Davison presents a dilemma with respect to praying for those we can't directly affect: either there are others who can help them, or there are not. If there are, then they should, but if they don't, there's no point in asking God to change their minds; for "if God is willing to override my choices about whether or not to help in response to your prayers, then God is not taking seriously my choices about whether or not to improve the world" (297). If there are no others who can help, "Choi has given us no reason to think that God would not provide for them, whether or not anyone asks for this" (297). Neither horn of this dilemma seems especially sharp. As for the first, just because God overrides your choices on rare occasion doesn't mean that, in general, he doesn't take your choices seriously. To be sure, if he overrode all of them, this would follow. But Choi's suggestion doesn't even remotely suggest anything so pervasive. As for the second, see section 4 above.

${ }^{25}$ Davison 2009, 297-98. 
What, exactly, is the argument here?

Here's a fair reconstruction of it. Suppose you ask God to heal your friend and suppose God is free with respect to doing so.

1. In general, if $S$ is free with respect to act $A$, then, if $T$ asks $S$ to $A$, T's asking $S$ to A does not cause $S$ to $A$.

2. In general, if T's asking $S$ to $A$ does not cause $S$ to $A$, then $T$ is not responsible for the result of S's A-ing and T does not deserve any credit for it.

3. So, given our suppositions, you are not responsible for your friend's healing and you do not deserve any credit for it.

We suspect that at least one of the premises here is false.

Consider the following case. Susan is a very skilled surgeon who is much sought after and has a full schedule. A cancer patient asks her to perform a life-saving surgery. Susan points to her packed schedule and reluctantly refuses. Susan's husband, Tony, hears of the patient, takes pity on him, and asks Susan to perform the extra surgery instead of taking the vacation they had planned. (Tony also makes some sacrifice of his own time to help Susan make this possible.) Suppose Susan is free with respect to her decision. In that case, although she is influenced by Tony's plea, she is not compelled. She decides to do it. To be sure, Tony's plea is not causally sufficient for her action but, nevertheless, it raises the probability of her doing it significantly; moreover, if he had not asked her, she would not have done it. As such, Tony's plea is a cause even if not a necessitating cause. If causing is not necessitating, premise (1) of Davison's argument is false.

If causing is necessitating however, then, even if Tony's plea did not cause Susan's decision to do the surgery, Tony is partially responsible for the patient's success and deserves some credit for it. (If the standards for causation are that high, causation is not necessary for responsibility and credit.) After all, he made a difference. Susan had declined to do the surgery. Tony's plea made it much more likely that she would do it. In that case, since Tony sacrificed some of his own time in his effort to bring about this result, he is responsible and worthy of the patient's gratitude for the role that he played. If causing is necessitating, premise (2) of Davison's argument is false. 
So whether or not causing is necessitating, Davison's argument has a false premise.

A final thought. Consider important historical figures we revere, such as Martin Luther King Jr. or Mahatma Gandhi. These men made a difference largely by influencing others to behave differently. The actions of the others were free, let's suppose; nevertheless, we still consider the result something that King and Gandhi are partially responsible for and we give them credit.

\section{THE PUZZLE OF SERIOUS PETITIONARY PRAYER}

The final objection we will consider, an objection derived from David Basinger, can be put like this. ${ }^{26}$

I concede that there is no tension between the claim that God does the best he can and the claim that our asking can make a difference to what God does. Nevertheless, a problem remains. Consider the difference between what we might call "basic goods" and "discretionary goods." Basic goods are goods like life, freedom from severe pain, debilitating illness and oppression, adequate food, water, shelter, and clothing, an education and so on. Discretionary goods are the "little extras," such as a parking space, a toy, a sunny day, a kind commentator, an even kinder audience, and the like. I concede that God's provision of discretionary goods might well depend on whether we pray, and hence that, strictly speaking, The Argument you mention at the outset is unsound. But God's provision of basic goods cannot depend on whether we pray. Parents sometimes reasonably make their provision of various goods hang on whether their children ask for them. The justification for this practice is similar to the reasons you suggest justify God in letting some good states of affairs hang on whether we pray. Doing so gives the child an opportunity to extend her responsibility, to exhibit love for her friends and siblings, and to foster healthy psychological attitudes such as gratitude. But can we imagine any of these reasons justifying a parent's letting some basic goods hang on whether she asks for them? Can we imagine a good parent refraining from giving a child adequate nutrition or an education

${ }^{26} 1995,481-82 ; 2003$, 259 ff. 
or warm clothing because she didn't ask for them? Of course not. That would be monstrous. But surely the same goes for God. Even if there is nothing amiss with his allowing discretionary goods to hang on our asking, he cannot-morally cannot-let basic goods do so.

But this flies in the face of what most practicing theists assume. They take it for granted that sometimes asking God to do something about basic goods will make a difference to what he does. They pray that the nineteen year old friend caught in an ambush in Afghanistan will not die from his chest wound; that the young woman in intensive care after attempting suicide will not die and will come to see reasons to live; that the tumor will melt away; that the bear will stop. When the going gets tough, when things of utmost importance are on the line, when survival is at stake, practicing theists tend to ask God for help. It would come as a disappointment to them, to say the very least, to learn that such petitions make no difference to what God does, although asking for a nice day for the church picnic might.

What we have here is what we might call the puzzle of serious petitionary prayer. As with the original puzzle, it too can be put into the form of an argument, as follows:

\section{The Revised Argument}

1. Either providing a basic good is the best God can do or it is not.

2. If it is, your asking won't make any difference to whether he does it.

3. If it is not, your asking won't make any difference to whether he does it.

4. So, your asking won't make any difference to whether God provides it.

Nothing you have said has any bearing on this argument at all. ${ }^{27}$ (Here ends the Basinger-inspired objection.)

What should we make of the puzzle of serious petitionary prayer and The Revised Argument?

\footnotetext{
${ }^{27}$ Thanks to Alec Baker for pressing this objection with us.
} 
We agree that it would be monstrous of God to permit people to starve, die of exposure or gunshot wounds, and so on just for the sake of the institution of petitionary prayer or even primarily for its sake. While the institution is valuable, it isn't that valuable. But then we neither said nor implied that it was. We neither said nor implied that God sometimes brings about good states of affairs if and only if we freely ask him, independent of any other reasons he might have for permitting the horrific evil and suffering our world contains. Let us explain.

We have been addressing the puzzle of petitionary prayer. We take it that that puzzle is not, at bottom, just the problem of evil. If we are wrong on this score-if the puzzle of petitionary prayer is, at bottom, just the problem of evil-then it is an unnecessarily troublesome way to get around to raising it and we have nothing new to add to the enormous literature on that topic. However, if we are right-if the puzzle of petitionary prayer is not, at bottom, the problem of evil-then the puzzle of serious petitionary prayer expresses a serious misunderstanding.

To see why, note that the parental analogy-which supports the revised premise (2) - is compelling precisely because we think that, although it would be permissible and loving for parents to withhold a toy, a chess match, or a play date until asked, it would not be permissible or loving to withhold food, or water, or shelter. And we think this precisely because we assume that there is no reason that justifies them in withholding them. Absent that assumption, things look very, very different. For if we really did think that the parents have independent reasons that justify them in lovingly permitting their child to suffer horrifically, then, even if those reasons are inscrutable to us, we could not think they were barbaric for setting things up so that some basic goods were provided if and only if their child or someone else asked for them. Similarly, if we really think that God has independent reasons that justify him in lovingly permitting your friend's cancer, the bear to maul you, and the soldier to die of her chest wounds, then, even if his reasons are inscrutable to us, we cannot think he is monstrous for setting the institution of serious petitionary prayer in place. To suppose otherwise is to mistake the puzzle of petitionary prayer for the problem of evil. They are not the same problem, however. 


\section{CONCLUSION}

We began with a puzzle, the puzzle of petitionary prayer. When we formulated it as an argument and scrutinized it, we discovered that it made a Crucial Assumption:

CA. God's bringing about a state of affairs in response to a petition cannot be better than the alternatives, and asking God to do something cannot change the moral status of his doing it, all by itself, independently of any other reason he has to do it.

We submit that CA is false. First, we mentioned in passing Cupit's account of how requests generate obligations and suggested that if it is correct, then asking God to do something can change the moral status of his doing it. Second, we defended at length Swinburne's and Choi's account of how it might be that God's bringing about a state of affairs in response to a petition is sometimes better than the alternatives. Third, we presented a version of Basinger's puzzle of serious petitionary prayer and showed how, once it is distinguished from the problem of evil, it is no more compelling than the original. Unless there is some other objection of which we are unaware, we conclude that the puzzle of petitionary prayer has been solved. ${ }^{28}$

\section{BIBLIOGRAPHY}

David Basinger 1995. "Petitionary Prayer: A Response to Murray and Meyers," Religious Studies 31: 475-84.

${ }^{28}$ For help with this paper, we thank Chris Bernard, E.J. Coffman, Ned Markosian, Ryan Wasserman, Dennis Whitcomb, the members of the Fall 2008 Philosophy of Religion seminar, Western Washington University, especially Alec Baker, the audience at the Pacific Division Meeting of the American Philosophical Association, Vancouver BC, April 2009, especially Joshua Bright, Tom Crisp, and our commentator on that occasion, Scott Davison, the audience at the Philosophy of Religion Conference, Baylor University, February 2010, and our commentator on that occasion, Shieva Kleinschmidt. We also thank Western for a Summer Research Grant that funded research and writing. We especially thank Hud Hudson for discussion and detailed comments. 
David Basinger 2003a. "God Does Not Necessarily Respond to Prayer” in eds. Michael L. Peterson and Ray van Arragon, Contemporary Debates in Philosophy of Religion, Malden, MA: Blackwell Publishing: 255-64.

David Basinger 2003b. "Reply to Murray," in eds. Michael L. Peterson and Ray van Arragon, Contemporary Debates in Philosophy of Religion, Malden, MA: Blackwell Publishing: 266-67.

John Calvin 1536 (1979). Institutes of the Christian Religion, trans. By Henry Beveridge, Grand Rapids, MI: Wm. B. Eerdmans Publishing Company.

Isaac Choi unpublished. "Is Petitionary Prayer Superfluous?"

Geoffrey Cupit 1994. "How requests (and promises) create obligations," in Philosophical Quarterly 44: 439-55.

Scott Davison 2009. "Petitionary Prayer," in The Oxford Handbook of Philosophical Theology, eds. Michael Rea and Thomas Flint, Oxford: Oxford University Press: 286-305.

Thomas Flint 1998. Divine Providence: The Molinist Account. Ithaca, New York: Cornell University Press.

Jerome Gellman 1997. "In Defense of Petitionary Prayer," Midwest Studies in Philosophy XXI: 83-97.

Daniel and Frances Howard-Snyder 1994. "How an Unsurpassable Being Can Create a Surpassable World," Faith and Philosophy, 1994, 260-68.

Michael Murray and Kurt Meyers 1994. "Ask and It Will be Given to You," Religious Studies 30: 311-30.

Michael Murray 2003a. "God Responds to Prayer" in eds. Michael L. Peterson and Ray van Arragon, Contemporary Debates in Philosophy of Religion, Malden, MA: Blackwell Publishing: 242-54.

Michael Murray 2003b. "Reply to Basinger," in eds. Michael L. Peterson and Ray van Arragon, Contemporary Debates in Philosophy of Religion, Malden, MA: Blackwell Publishing: 264-65.

Eleonore Stump 1979. "Petitionary Prayer," American Philosophical Studies 16: 81-91.

Richard Swinburne 1998. Providence and the Problem of Evil, Oxford: Oxford University Press. 